\title{
COMMUNICATION SKILLS IN TOURISM STUDIES CURRICULA IN SLOVENIA: THE CASE OF THE SLOVENE LANGUAGE SKILLS OF TOURISM STUDENTS
}

Jasna Potočnik Topler, Faculty of Tourism, Brežice, Slovenia

\begin{abstract}
This paper examines communication skills of tourism students in Slovenia. Besides rhetoric skills and speaking foreign languages, for tourism students, mastering their mother language is significant. The survey has shown that the students of tourism enrolled at the Faculty of Tourism of the University of Maribor are not systematically trained in their mother language skills at the university level. Consequently, during oral exams and their oral presentations tourism students display strong traces of their dialects, and they make pronunciation mistakes. The most common students' mistakes are the following: incorrect pronunciation of some proper names, pronouncing the wrong syllable, and the incorrect pronunciation of the Slovene participles.
\end{abstract}

Keywords: Speech, Tourism, Language, Communication, Pronunciation

\section{KOMUNIKACIONE VEŠTINE U STUDIJSKIM PROGRAMIMA TURIZMA U SLOVENIJI: PRIMER VLADANJA SLOVENAČKIM JEZIKOM}

Sažetak

Ovaj rad istražuje komunikacione veštine studenata turizma u Sloveniji. Osim retorskih veština i poznavanja stranih jezika, za studente turizma je značajno i dobro vladanje maternjim jezikom. Istraživanje je pokazalo da studenti Fakulteta za turizam sa Univerziteta u Mariboru nisu sistematski obučeni kada su u pitanju veštine maternjeg jezika na univerzitetskom nivou. Samim tim, tokom usmenih ispita i usmenih prezentacija, kod studenata turizma su prisutni jaki tragovi njihovih dijalekata, kao i greške u izgovoru. Najčešće greške studenata su nepravilan izgovor nekih ličnih imenica, izgovaranje pogrešnih slogova i nepravilan izgovor slovenačkog participa.

Ključne reči: govor, turizam, jezik, komunikacija, izgovor

TIMS Acta (2017) 11, 81-85 


\section{Introduction}

The tourism sector is one of the most important sectors of the Slovene economy since it represents around $13 \%$ of the country's GDP according to the estimations for 2015 (Grapulin, 2015). As far as competitiveness of destinations is concerned, according to Gomezelj Omerzel (2006:174), Slovenia is considered as "above average in all attributes on this dimension". Favourable climate, unspoiled nature and traditional arts were accorded the highest ratings in Gomezelj Omerzel's research (2006:174). Since 2007, the country is branding itself by the slogan "I feel Slovenia", which was created to improve Slovenia's competitiveness in different areas. Consequently, education and research for the tourism sector are gaining importance in Slovenia. In the recent years, significant efforts have been made in upgrading tourism programs at university (graduate and post-graduate) levels, teaching tourism-specific subjects has been improved, also by creating, re-creating and upgrading tourism studies curricula at different universities, faculties and colleges in Slovenia. The present survey concentrates on analysing mother tongue (lingua materna) communication skills of tourism students in Slovenia in order to detect the actual shortcomings of the tourism students and further on actively work on the detected shortcomings to improve communication in the Slovene language. The communicative aspect, and especially knowledge of languages is of great importance for students who are in the process of education for the tourism sector. Not only knowledge of foreign languages is significant, but also communication skills in general. In Slovenia, there are more than 10 bachelor and master programs of tourism studies, available at many private colleges and at three Slovene universities, i.e. University of Ljubljana, University of Maribor and University of Primorska (www.nakvis.si). According to the World Tourist Organization (UNWTO), tourism has become "one of the fastest growing economic sectors in the world". Since the tourism sector is growing and the forecasts for the future of this sector are very positive (UNWTO), tourism studies are among the popular ones in Slovenia.

Analysing the curricula of the accredited tourism programs in Slovenia showed that teaching the Slovene language, which is the mother tongue of the majority of the students currently enrolled to tourism programs in Slovenia, is not included in the curricula at the university level, but the majority of lectures (except teaching foreign languages) are in the Slovene language (according to the Higher Education Act, ZViS), at the Slovene universities the language of instruction is Slovene, yet parts of the curriculum may be conducted in a foreign language, in cases of visiting professors or a large number of participating exchange students). Curricula, however, include subjects on communication, communication skills, rhetoric, and media, but not any subjects dealing with mastering the Slovene language, its grammar, writing, and speaking skills.

\section{Methodology and theory background}

The methods of participant observation and pronunciation assessment by listening have been employed in examining the so-called speech culture (knowledge of standard spoken language) of the tourism students originating from Slovenia. Participant observation is used in a variety of disciplines for gathering data, also in social sciences and linguistics. Participant observation is the process enabling researchers to learn about the activities of the people under study in the natural setting through observing and participating in those activities. It provides the context for development of sampling guidelines and interview guides (DeWalt \& DeWalt, 2002 in Kawulich, 2005). According to Schensul, Schensul, and LeCompte (1999) participant observation is "the process of learning through exposure to or involvement in the day-to-day or routine activities of participants in the researcher setting" (1999:91). Listening, according to the Merriam-Webster Dictionary definition (www.merriam-webster.com), is paying attention to someone in order to hear what is being said. In the current survey, 137 Slovene students of tourism giving their presentations in the Slovene language were observed by active listening. The sample consisted of 98 female and 39 male students, aged between 18 and 31. At the tourism studies in Slovenia, according to the sample, female students prevail. Participant observation took place during obligatory students' presentations and obligatory practical work on various occasions and days from November 2014 until January of 2017 without giving 
information to students that their speaking skills were being observed for further analysis. The information about observation was not disclosed to the observed students before the actual observation in order to keep their usual behaviour during their speeches.

\section{Speaking skills}

Languages play a significant role in the tourism sector. According to Arbib (2012:31), languages "are acquired anew (and may be slightly modified thereby) in each generation". Consequently, languages change all the time, and it can be expected that speaking of young generations differs from speaking of old generations.

Weiler and Black (2014:116) emphasize the role of communication skills in tourism, especially in the light of professionalism in the tourism sector (Mak, et al., 2011). Weiler and Walker (2014:91) also point out the importance of public speaking skills in the tourism sector, the quality of voice, diction, etc., (2014). Thus, training a future worker in tourism and provide him with all the proper skills is a challenging task.

When language skills are observed, one aspect of tourism students' knowledge of languages is the level to which their speech corresponds to the norms of the received pronunciation of Slovene and the standard Slovene language as suggested in Slovenski pravopis (Toporišič, et al., 1990; 2003), which is the essential book of pronunciation rules in the Slovene language according to Dobrovoljc and Bizjak Končar (2015). The so-called speech culture is an important component of the standard Slovene. In Slovenia, the history of speech culture is long and diverse - ever since 1550, when Primož Trubar published the first book in the Slovene language, the Slovene linguists have also been concerned with the question of the Slovene pronunciation (Ahačič, 2008). Before the new Slovenski pravopis was published in 2001 (its $2^{\text {nd }}$ edition in 2003), also the dictionary titled Slovar slovenskega knjižnega jezika (Toporišič, et al., 1995) was essential in resolving the questions of the Slovene pronunciation (Dobrovoljc \& Lengar Verovnik, 2015). In the last century, important contribution to the speech culture has been made by the linguist Jože Toporišič (the main author of Slovenski pravopis and Slovar slovenskega knjižnega jezika), and by lectors, who, as Vrtačnik and Tivadar state (2015), warned that standard spoken Slovene differs from standard written Slovene.

\section{Results of the analysis}

In the current survey, a lot of linguistic mistakes and incorrect pronunciation has been noticed observing 137 Slovene students of tourism. Due to space limitations, further on, only mistakes made by more than $35 \%$ of students will be described.

All the observed tourism students (137 or $100 \%$ ) use filler words, such as "a ne", "ja”, "torej", "mmmmmm", "pravzaprav", "bom rekel", "prav", "kao", "ful”, etc; which is commonly displayed in communication and in public speaking in Slovenia, but it is considered a sign of bad speech culture.

Proper names, such as the names of persons and places (geographical proper names) are often pronounced incorrectly. Among the participating students, all of them (100\%) pronounced at least one of the following words incorrectly: "Úkrajina" instead of "Ukrajína”, "Velíka Britanija” instead of "Vélika Britanija”, "Váršava" instead of "Varšáva". The observed tourism students often (98 or $71,5 \%$ ) used incorrect forms of declinations of proper names, such as "Mirkota", "Markotu", "Vladota", "Benota”, etc. instead of "Mirka”, "Marku”, "Vlada", "Bena”.

An outstanding mistake observed with 61 (44,5\%) tourism students is the so-called semi-formal addressing of people ('polvikanje' in Slovene) instead of formal addressing ('vikanje'), which is the only allowed and acceptable form in the standard Slovene; forms as "boste šel", "boste vidu", "ste se uredila", "boste navdušen", "ne boste razočaran", "boste utrujena", etc. are incorrect. The correct forms of formal addressing are the following: "boste šli", "boste videli", "ste se uredili", "boste navdušeni", "ne boste razočarani", "boste utrujeni", etc.

Some of the most common examples of pronunciation mistakes are the following:

- Pronuncing [I] instead of [lj], for example [kluč], [grable] (instead of the standard Slovene [ključ], [grablje], occurring with 86 or $62,7 \%$ of students; 
- Pronouncing the infinitive without the final $\mathrm{i}$, for example [nôsit], [pêljat], [písat], [krênit], etc., occurring with 66 or $48,1 \%$ of tourism students.

\section{Discussion}

The survey showed that the knowledge of the standard spoken Slovene among tourism students is very weak. Although standardised Slovene is taught firstly to children in primary schools, and later to students in secondary schools and colleges, teachers who are well-educated in the field of phonetics and know how to pronounce at least the vocabulary from their professional areas correctly in standard Slovene are rare. Also, in the media, in the Slovene parliament, and in other public places, wrong pronunciation of the Slovene can be heard. Consequently, correct pronunciation is sometimes perceived as unusual or even wrong despite the fact that it is correct according to Slovenski pravopis (SP).

Due to insufficient knowledge of phonetics, the correct pronunciation in Slovene can mistakenly be considered wrong, for example, the correct pronunciation of the I-participle "narédil je načrt za grad", saying number 2 "dve" instead of the incorrect "dva", and the pronunciation of semi vowels or the schwa sounds [ə] is often considered as the trace of the Ljubljana dialect despite the fact that the endings of many nouns containing vowels should be pronounced with a schwa [ə] in standard Slovene.

Pronunciation knowledge (for example, pronunciation of the preposition $\mathrm{v}$, vowels and semi vowels, adoption and declension of words from other languages etc.) is a significant part of language culture in Slovene, and this knowledge should somehow be acquired also by tourism students.

According to Kalin Golob (2001) it does not only matter what you say, but above all, how you say it. The knowledge of the rules of rhetoric is not sufficient. People who speak in public should have respect for the people in the audience, and they should also have good knowledge of linguistic rules, which include pronunciation, orthoepy, phonetics and sentence phonetics.
A culturally informed speaker tries to avoid filler words (any means of language that is used in speech without the real need, and which does not affect the informative, persuasive, argumentative or aesthetic level of the speech), because they are distracting. Fillers tend to be used while thinking what to say, how to answer the question. The following are among the most common fillers in the Slovene language: "Naj povem, da ..."; "Treba je reči, da ..."; "Moram povedati ..."; "Bom rekel, da ..."; "Poglejte, ..." (followed by a question) ... The repetition of the schwa sounds, for example "әәә, әәә, әәә", is the most disturbing among fillers. There are also words that individual speakers use often or even several times in one sentence. These are personal fillers. Among the most common are the following: "torej", "pravzaprav", "a ne", "vsekakor", "prav". Also such fillers should try to be avoided (Kalin Golob, 2001).

\section{Conclusion and implications}

The survey showed that in Slovenia additional attention should be given to the communication skills of tourism students in their mother tongue since the students' knowledge in this area is weak. Speech culture and spoken standard Slovene should become parts of the education modules at tourism programs in Slovenia because good communication skills in the mother tongue are essential for the future workers of the tourism sector. It is essential that tourism students as future professionals who will speak in public obey the rules of standard Slovene pronunciation from Slovenski Pravopis and that they have basic knowledge of standard Slovene phonetics because verbal nonsophistication does not only reflect the ignorance, but is also a sign of disrespect towards the listeners - guests, visitors, tourists, travellers. By including the topics of phonetics of the Slovene language into the curricula for tourism students it would be possible to rectify the shortcomings. With the education and practice of those who plan the development of the professions of the tourism sector in Slovenia, steps forward could be made in the right direction to a higher level of speech culture of the Slovene language, and to the higher quality of services in tourism. 


\section{IZJAVA}

\section{Autorka je svojom izjavom potvrdila nepostojanje bilo kakvog sukoba interesa.}

\section{LITERATURA}

Ahačič, K. (2008). Govor in njegov zapis v prvih stoletjih zgodovine slovenskega knjižnega jezika. Ed.: Primož Vitez: Spisi o govoru. Ljubljana: Znanstvenoraziskovalni inštitut Filozofske fakultete. 111- 124.

Arbib, A. M. (2012). How the Brain got Language: The Mirror System Hypothesis. Oxford, New York: Oxford University Press.

Country Brand: I feel Slovenia. (2007). Retrieved from http://www. ukom.gov.si/en/promotion_of_slovenia/country_brand_i_feel_ slovenia/ (July 2016).

Dobrovoljc, H., \& Bizjak Končar, A. (2015). Pravopisno slovaropisje na Inštitutu za slovenski jezik Frana Ramovša ZRC SAZU. Slavia Centralis, 8(1), 34-50. Retrived from: https://kuscholarworks. ku.edu/bitstream/handle/1808/18718/04_SCN_1_2015 Dobrovoljc.pdf.

Dobrovoljc, H., \& Lengar Verovnik, T. (2015). Slovar pravopisnih težav kot sopotnik pravopisnih pravil in pomenskorazlagalnega slovarja. Simpozij Obdobja 34: Slovnica in slovar - aktualni jezikovni opis. Ed.: Mojca Smolej. Ljubljana: Filozofska fakulteta.

Gomezelj Omerzel, D. (2006). Competitiveness of Slovenia as a Tourist Destination. Managing Global Transitions, 4(2), 167-189.

Grapulin, T. (2015). Slovenski turizem bo rasel, a smo še daleč za Avstrijo. Finance 59/2015, 24. 3. 2015. Retrieved from http:// www.finance.si/8819462. (July 2016).

Kalin Golob, M. (2001). Jezikovne reže. Ljubljana: GV Revije: PP Pravna praksa.

Kawulich, B. B. (2005). Participant Observation as a Data Collection Method. Forum: Qualitative Social Research Sozialforschung, Vol. 6, No. 2, Art. 43. Retrived from: http://www.qualitative-research net/index.php/fqs/article/view/466/996\#g2 (July 2016).

Mak, A. H. N., Wong, K. K. F., \& Chang, R. C. J. (2011). Critical issues affecting the service quality and professionallism of the tour guides in Honk Kong and Macau. Tourism Management, 32(6) 1442-1452.

Merriam-Webster Dictionary. http://www.merriam-webster.com/ dictionary/listen

National agency of the Republic of Slovenia for the quality of higher education. (2016). NAKVIS. Retrieved from http://www.nakvis.si/ sl-SI/Content/Details/46 (July 2016).
Schensul, S. L.., Schensul, J. J., \& LeCompte, M. D. (1999). Essential ethnographic methods: observations, interviews, and questionnaires (Book 2 in Ethnographer's Toolkit). Walnut Creek, CA: AltaMira Press.

Toporišič, J. (Ed.). (1990). Slovenski pravopis 1: Pravila. Ljubljana: DZS

Toporišič, J. (Ed.). (1995). Slovar slovenskega knjižnega jezika (SSKJ). Ljubljana: SAZU.

Toporišič, J. (Ed.). (2003). Slovenski pravopis. Ljubljana: Založba ZRC, ZRC SAZU: Delo, 2nd Edition.

UNWTO Tourism Highlights 2015 Edition. http://www.e-unwto.org/ doi/pdf/10.18111/9789284416899

Vrtačnik, M., \& Tivadar, H. (2015). Odrski govor na Slovenskem z vidika pravorečja. Simpozij Obdobja 34: Slovnica in slovar - aktualni jezikovni opis. Ed.: Mojca Smolej. Ljubljana: Filozofska fakulteta. $837-845$.

Weiler, B., \& Black, R. (2014). Tour guiding research: Insights, Issues, and Implications. Bristol: Channel View Publications.

Weiler, B. \& Walker, K. (2014). Enhancing the visitor experience: reconceptualizing the tour guide's communicative role. Journal of Hospitality \& Tourism Management. 21, 90 - 99.

World Tourism Organization UNWTO http://www2.unwto.org/ content/why-tourism (July 2016).

Zakon o visokem šolstvu. Retrived from http://pisrs.si/Pis.web/ pregledPredpisa?id=ZAKO172 (July 2016).

Datum prijave: 31.05.2017.

Datum prihvatanja: 22.06.2017.

\section{Kontakt}

Jasna Potočnik Topler, Faculty of Tourism, Brežice, Slovenia, Cesta prvih borcev 36,

E-mail: jasna.potocnik1@um.si 